\title{
DOES HEALTH INSURANCE STATUS AFFECT CHOICE OF SPECIALIST?
}

\author{
Prita Yuliana Irnawati'), Harsono Salimo²), Yulia Lanti Retno Dewi3) \\ 1)Masters Program in Public Health, Universitas Sebelas Maret \\ 2)Department of Pediatrics, Dr. Moewardi Hospital, Surakarta \\ 3)Faculty of Medicine, Universitas Sebelas Maret
}

\begin{abstract}
Background: A demand-driven healthcare system has increasingly focused the importance of patient healthcare provider choice. Important reasons for promoting patient choice have been to reduce waiting times and to encourage competition between providers. This study aimed to determine the effect of health insurance status on the choice of specialist.

Subjects and Method: This was a case control study conducted at Sangkrah community health center, Surakarta, in January 2017. A sample of 164 mothers was selected by fixed disease sampling. The dependent variable was mother's choice to visit a pediatrician. The independent variables were membership of the national health insurance, perceived benefit, perceived barrier, perceived severity, and family income. The data were collected by questionnaire and analyzed by a multiple linear regression.

Results: Mother's choice to visit a pediatrician was positively affected by perceived benefit ( $\mathrm{b}=0.89 ; 95 \% \mathrm{CI}=1.24$ to $4.8 ; \mathrm{p}=0.009)$ and perceived seriousness $(\mathrm{b}=0.92 ; 95 \% \mathrm{CI}=1.18$ to $5.32 ; \mathrm{p}=0.016)$, but was negatively affected by perceived barrier ( $\mathrm{b}=-0.77 ; 95 \% \mathrm{CI}=0.23$ to $0.91 ; \mathrm{p}=0.026)$ and low family income $(b=-0.66 ; 95 \% \mathrm{CI}=0.9$ to $3.6 ; \mathrm{p}=0.067)$. The effect of health insurance membership on mother's choice to visit a pediatrician was statistically non significant.

Conclusion: The effect of health insurance membership on mother's choice to visit a pediatrician is statistically non significant. Mother's choice to visit a pediatrician is positively affected by perceived benefit and perceived seriousness, but is negatively affected by perceived barrier and low family income.
\end{abstract}

Keywords: mother's choice, pediatrician, national health insurance

\section{Correspondence:}

Prita Yuliana Irnawati. Masters Program in Public Health, Sebelas Maret University, Surakarta, Jl. Ir. Sutami No. 36 A, 57126, Surakarta, Central Java. Email: pritayuliana@gmail.com. Mobile:+6287835140534. 